Jurnal Pendidikan Matematika : Judika Education

Volume 2, Nomor 1, Januari-Juni 2019

e-ISSN : 2614-6088

p-ISSN : 2620-732X

DOI: https://doi.org/10.31539/judika.v2i1.700

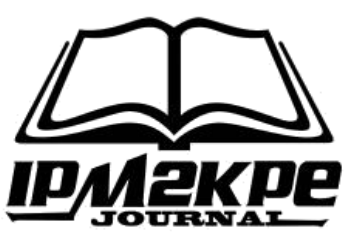

\title{
ANALISIS LEVEL KINERJA PRACTITIONER MELALUI AKTIVITAS BELAJAR SISWA
}

\author{
Eric Dwi Putra ${ }^{1}$, Indah Rahayu Panglipur ${ }^{2}$ \\ IKIP PGRI Jember ${ }^{1,2}$ \\ $\underline{\text { dwieric454@gmail.com }}{ }^{1}$
}

\begin{abstract}
ABSTRAK
Tujuan penelitian, mengetahui level kinerja practitioner melalui aktivitas belajar siswa. Level kinerja practitioner siswa dilihat ketika menyelesaikan permasalahan matematika (soal cerita) subpokok bahasan bilangan. Metode penelitian yang digunakan adalah deskriptif kuantitatif. Teknik analisa menggunakan uji validitas dan triangulasi sumber. Pada penelitian ini subyek siswa kelas VII diambil sebanyak 6 orang. Pengambilan data menggunakan observasi dan soal (permasalahan). Data di observasi dengan menggunakan instrumen lembar observasi, sedangkan soal dengan media realistik. Hasil penelitian, validasi instrument pada lembar observasi menggunakan nilai $\mathrm{V}_{\mathrm{a}}$ untuk soal tes diperoleh hasil 2,9 dengan demikian instrumen dikatakan valid. Berdasarkan hasil observasi ST memenuhi semua kegiatan dengan baik namun pada kegiatan yang terkait keberanian masih belum dapat dikatakan selalu berani dalam menanggapi dan mengajukan pertanyaan/pendapat dengan tegas, SS memenuhi 3 dari 6 kegiatan siswa dengan baik. Hasil ini sama untuk 2 subyek yang diambil. SR memenuhi 5 dari 6 kegiatan siswa dengan baik. Hasil ini sama untuk 2 subyek yang diambil. Simpulan, level kinerja Practitioner siswa mempunyai perbedaan pemenuhan standar kritisnya melalui aktivitas belajar siswa. Siswa dengan kategori kemampuan tinggi (ST) dapat memenuhi seluruh indikator standart kritis sedangkan aiswa dengan kategori kemampuan sedang (SS) dan rendah (SR) tidak dapat memenuhi.
\end{abstract}

Kata Kunci : Level Kinerja Practitioner, Aktivitas Belajar

\begin{abstract}
The purpose of the study, determine the level of performance of practitioners through student learning activities. The level of student practitioner performance is seen when solving mathematical problems (story problems) sub-topics of numbers. The research method used is quantitative descriptive. The analysis technique uses validity test and source triangulation. In this study the subjects of class VII students were taken as many as 6 people. Retrieval of data using observations and questions (problems). Data were observed using an observation sheet instrument, while questions with realistic media. The results of the study, the validation of the instrument on the observation sheet using the Va value for the test questions obtained 2.9 results thus the instrument is said to be valid. Based on the results of observations ST satisfies all activities well but in activities related to courage still can not be said to always be brave in responding and asking questions / opinions expressly, SS fulfills 3 out of 6 student activities well. These
\end{abstract}


results are the same for the 2 subjects taken. SR fulfills 5 out of 6 student activities well. These results are the same for the 2 subjects taken. Conclusions, the Practitioner student's level of performance has different levels of fulfillment of critical standards through student learning activities. Students with high ability category (ST) can meet all critical standard indicators while students with medium (SS) and low (SR) ability categories cannot fulfill.

Key Words: Performance Level Practitioners, Learning Activities

\section{PENDAHULUAN}

Pendidikan merupakan salah satu proses penting dalam hal mewujudkan kompetensi sumber daya manusia yang akan dinginkan. Kegiatan penting dalam proses pendidikan yaitu pelaksanaan proses kegiatan belajar mengajar saat di kelas (Panglipur, 2006).

Peningkatan mutu pendidikan dari proses kegiatan belajar mengajar yang baik tentunya akan berdampak terhadap pemahaman siswa pada yang telah diberikan oleh guru. Di sisi lain seorang siswa merupakan salah satu pelaku utama dalam kegiatan proses pembelajaran yang selalu akan dituntut untuk aktif melakukan proses dan mengolah informasi yang telah diterima saat didalam proses pembelajaran. Didalam proses pembelajaran siswa tidak hanya mendengar dan melihat guru di saat proses pembelajaran berlangsung (Panglipur, 2006). Tetapi seorang siswa harus mampu dalam melibatkan dirinya disaat proses pembelajaran berlangsung. Seorang siswa harus selalu semangat dalam melakukan aktivitas didalam proses pembelajaran, jika rasa semangat siswa berkurang maka dapat mengurangi aktivitas belajar.

Aktivitas belajar adalah suatu proses kegiatan atau perilaku yang telah terjadi waktu proses kegiatan belajar mengajar berlangsung (Amalia \& Panglipur, 2019). Kegiatan-kegiatan tersebut yaitu kegiatan yang mengarah kepada suatu proses didalam kegiatan belajar misalnya melakukan pertanyaan, mengajukan suatu ide atau pendapat, menjawab dari pertanyaan guru atau teman sejawat.

Aktivitas Belajar siswa dalam bentuk kegiatan siswa diantaranya visual activities, motor activities, mental activities maupun emotional activities (Rahmadani \& Anugraheni, 2017). Dalam proses kegiatan pembelajaran matematika, aktivitas belajar dari seorang siswa harus mampu terlibat dengan aktif.

Menurut Putra (2008) Aktivitas belajar didalam pembelajaran matematika merupakan suatu bentuk yang khusus dari aktivitas belajar, yaitu merupakan segala bentuk dari aktivitas siswa yang telah dilakukan didalam rangka untuk mengungkapkan dari ide-ide matematika. Aktivitas belajar yaitu seseorang yang melakukan proses berpikir tentang beberapa hal untuk merenungkan suatu ide-ide, serta perlu disertai dengan berbagai perbuatan ataupun aktivitas fisik.

Proses berpikir adalah suatu aktivitas yang melibatkan terhadap banyak aktivitas mental terhadap penyelesaian permasalahan. Suatu 
Kemampuan berpikir dari setiap siswa akan berbeda-beda, karena tergantung terhadap bagaimana siswa tersebut dalam melatih maupun mengembangkannya.

Kemampuan dari berpikir siswa dapat dilatih serta dapat ditingkatkan secara rutin maupun bertahap untuk melakukan proses penyelesaian permasalahan yang dapat membutuhkan pengetahuan dalam tingkat tinggi, maupun salah satunya yaitu dengan cara mengoptimalkan suatu kemampuan kinerja dari siswa serta membutuhkan usaha dari siswa. Usaha tersebut yang dapat siswa maksimalkan dengan pengalaman dari pengetahuan siswa yang telah dimiliki sehingga kemampuan dari siswa terhadap kinerja siswa dapat meningkat

Penilaian kinerja yaitu merupakan penilaian dari hasil suatu pengamatan maupun observasi terhadap beberapa aktivitas siswa yang terjadi selama proses pembelajaran didalam kelas (Panglipur \& Putra, 2019). Penilaian kinerja (Performance Assessment) merupakan salah satu cara guru untuk dapat mengetahui seberapa besar penguasaan siswa terhadap materi maupun pelajaran matematika. Hal tersebut dapat dilaksanakan dengan cara mengamati siswa dalam melakukan suatu penyelesaian pekerjaan dalam aktivitas belajar (Panglipur, 2016).

Saat proses pelaksanaan penilaian sebaiknya berhubungan dengan kondisi dunia nyata, sehingga seorang siswa akan dapat memanfaatkan terhadap pengetahuan maupun kemampuan yang telah dimiliki untuk menyelesaikan permasalahan yang berhubungan dengan matematika. (

Menurut Burwell, Young \& Pickup (2003) Terdapat empat level dari performance yang ditetapkan oleh Exemplars, salah satu level dari suatu kinerja (performance) siswa yaitu Practitioner .

Pada level Practitioner ini, seorang siswa sudah mulai mampu dalam memiliki strategi yang benar dalam melakukan penyelesaian masalah, alasan maupun proses dari pembuktian sudah terlihat logis, serta mampu melakukan komunikasi ide secara parsial, mampu menghubungkan pengetahuan lama yang dimiliki oleh siswa dengan pengetahuan yang baru, serta siswa mampu mengkontruk dari suatu konsep matematika meskipun masih sebagian proses dalam pengkontruksiannya (Irawan, Susanto \& Kurnianti, 2015).

Sesuai dengan indicator pada level Practitioner maka soal atau permasalahan yang diberikan kepada siswa lebih tepat menggunakan media realistik.

Berdasarkan permasalahan diatas, maka peneliti melakukan penelitian dengan judul " Analisis Level Kinerja Practitioner melalui Aktivitas Belajar Siswa”. Adapun tujuan penelitian ini adalah untuk mengetahui level kerja practitioner melalui aktivitas belajar siswa.

\section{METODE PENELITIAN}

Peneliti ini menggunakan jenis penelitian deskriptif yang dilakukan di SMP PLUS Al Amien Ambulu kelas VII. Ketertarikan peneliti mengambil tema ini untuk diteliti adalah untuk mengetahui bagaimana level kinerja 
Practitioner siswa kelas VII dalam menyelesaikan permasalahan (soal) matematika berdasarkan aktivitas belajar siswa. Peneliti bermaksud mendeskripsikan atau menggambarkan level kinerja Practitioner siswa melalui aktivitas belajar dalam menyelesaikan permasalahan.

Dalam penentuan subjek terlebih dahulu mengambil nilai pada materi sebelumnya yang melalui daftar nilai yang dimiliki oleh guru matematikia di kelas tersebut. Hal ini bertujuan untuk mengkategorikan siswa pada kemampuan tinggi, kemampuan sedang dan kemampuan rendah. Selanjutnya memilih dua siswa dari masing-masing kategori yang akan diberikan soal (permasalahan) melalui media realistik, berikutnya subyek diobservasi aktivitas belajarnya pada saat menyelesaikan permasalahan.

Teknik pengumpulan data yang digunakan adalah observasi dan soal (permasalahan). Data Obeservasi dengan menggunakan instrumen lembar observasi, sedangkan soal (permasalahan) dengan media realistik. Langkah selanjutnya dengan melakukan uji validitas pada instrument lembar observasi.

Menurut Hobri (2010), menentukan rerata hasil validasi dari semua validator untuk setiap indikator dengan rumus :

dengan :

$$
I_{i}=\frac{\sum_{j=1}^{n} V_{j i}}{v}
$$

$V_{j i}=$ data nilai dari validator ke- $j$

terhadap indikator ke- $i$

$j=$ validator

$i=$ indikator

$v=$ banyaknya validator
Dengan nilai $I_{i}$, ditentukan nilai rerata untuk setiap aspek $A_{i}$ dengan persamaan:

$$
A_{i}=\frac{\sum_{i=1}^{m} I_{i}}{m}
$$

dengan :

$A_{i}=$ nilai rerata aspek

$I_{i}=$ rerata nilai untuk aspek ke- $i$

$i=$ aspek yang dinilai

$m$ = banyaknya aspek

Dengan nilai $A_{i}$, kemudian ditentukan nilai rerata total untuk semua aspek $V_{a}$ dengan persamaan :

$$
V_{a}=\frac{\sum_{i=1}^{n} I_{i}}{n}
$$

dengan :

$V_{a}=$ nilai rerata total semua aspek

$I_{i}=$ rerata nilai untuk aspek ke- $i$

$i=$ aspek yang dinilai

$n=$ banyaknya aspek

hasil $V_{a}$ yang diperoleh kemudian ditulis pada kolom yang sesuai, juga dalam tabel 1. Instrumen dinyatakan valid dan dapat digunakan jika nilai $V_{a} \geq 2,5$.

Tabel 1.

Kriteria Validitas Instrumen

\begin{tabular}{lc}
\hline \multicolumn{1}{c}{ Nilai $\boldsymbol{V}_{\boldsymbol{a}}$} & Tingkat Kevalidan \\
\hline \multicolumn{1}{c}{$V_{a}=3$} & Sangat Valid \\
\hline $2,5 \leq V_{a}<3$ & Valid \\
\hline $2 \leq V_{a}<2,5$ & Cukup Valid \\
\hline $1,5 \leq V_{a}<2$ & Kurang Valid \\
\hline $1 \leq V_{a}<1,5$ & Tidak Valid \\
\hline \multicolumn{3}{c}{ Data hasil aktivitas belajar } \\
siswa selama mengerjakan soal \\
(permasalahan) berdasarkan lembar \\
observasi yang telah diisi oleh \\
observer, yang kemudian akan \\
dikategorikan ke dalam level kinerja \\
siswa sesuai pedoman penskoran \\
level kinerja siswa yang masuk pada \\
level Practitioner. Setelah
\end{tabular}


pengelompokkan selesai maka dilakukan penyimpulan dengan rerata total skor setiap indikator pada tabel 2.

Tabel 2.

Kategori Level Kinerja Siswa

\begin{tabular}{cc}
\hline Nilai $\boldsymbol{x}$ & Level Siswa \\
\hline$x=4$ & Expert \\
\hline $3 \leq x<4$ & Practitioner \\
\hline $2 \leq x<3$ & Apprentice \\
\hline $1 \leq x<2$ & Novice \\
\hline
\end{tabular}

Sedangkan untuk pengecakan keabsahan data menggunakan triangulasi sumber yaitu hasil data siswa dalam katogeri yang sama pada masing-masing kategorinya.

\section{HASIL PENELITIAN}

Hasil yang diperoleh dari validasi instrument pada lembar observasi adalah Nilai $\mathrm{V}_{\mathrm{a}}$ untuk soal tes diperoleh hasil 2,9 dengan demikian instrumen dikatakan valid sesuai dengan kriteria apabila berada pada kategori valid jika $2,5 \leq \mathrm{V}_{\mathrm{a}}<3$. Dalam pemilihan subyek penelitian diperoleh 6 siswa dengna rincian 2 siswa kategori berkemampuan tinggi (ST), 2 siswa kategori berkemampuan sedang (SS), dan 2 siswa kategori berkemampuan rendah (SR). Selanjutnya subyek diberikan soal (permasalahan) berupa media realistik.

Pada saat siswa mengerjakan soal tersebut observer mengamati aktivitas belajar siswa dengan menggunakan lembar observasi. Hasil tes menunjukan bahwa level Practitioner siswa melalui aktivitas pada masing-masing subyek dapat dilihat dari tabel berikut

Tabel 3.

Aktivitas Belajar Siswa ST1

\begin{tabular}{|c|c|c|}
\hline Subyek & Kegiatan siswa & Indikator \\
\hline \multirow[t]{4}{*}{ ST1 } & Visual activities & $\begin{array}{l}\text { Siswa dapat memperhatian dengan baik media yang } \\
\text { digunakan untuk demonstrasi permaslaahan }\end{array}$ \\
\hline & Motor activities & Siswa mampu membuat konstruksi dengan tepat \\
\hline & Mental activities & $\begin{array}{l}\text { a. Siswa dapat memberikan tanggapan yang tepat dan } \\
\text { sesuai dengan permasalahan yang diberikan } \\
\text { b. Siswa mampu dengan baik memecahkan soal } \\
\text { (permasalahan) dengna cara yang sesuai }\end{array}$ \\
\hline & Emotional activities & $\begin{array}{l}\text { a. Siswa terlihat sangat bersemangat dalam } \\
\text { menyelesaikan permasalahan } \\
\text { b. Siswa dengan berani dalam menanggapi dan } \\
\text { mengajukan pertanyaan/pendapat dengan tegas }\end{array}$ \\
\hline
\end{tabular}

Berdasarkan tabel 3 dapat belajarnya memenuhi semua kegiatan diketaui bahwa ST1 dalam aktivitas dengan baik.

Tabel 4.

Aktivitas Belajar Siswa ST2

\begin{tabular}{lll}
\hline Subyek & \multicolumn{1}{c}{ Kegiatan siswa } & \multicolumn{1}{c}{ Indikator } \\
\hline ST2 & Visual activities & $\begin{array}{l}\text { Siswa dapat memperhatian dengan baik media yang } \\
\text { digunakan untuk demonstrasi permasalahan }\end{array}$ \\
\cline { 2 - 4 } & Motor activities & Siswa mampu membuat konstruksi dengan tepat \\
\cline { 2 - 4 } & Mental activities & a. Siswa dapat memberikan tanggapan yang tepat dan \\
\hline
\end{tabular}


sesuai dengan permasalahan yang diberikan

b. Siswa mampu dengan baik memecahkan soal (permasalahan) dengna cara yang sesuai

Emotional activities a. Siswa terlihat sangat bersemangat dalam menyelesaikan permasalahan

b. Siswa dengan kurang berani dalam menanggapi dan mengajukan pertanyaan/pendapat dengan tegas

Berdasarkan tabel 4 dibawah ini dapat diketaui bahwa ST2 dalam aktivitas belajarnya memenuhi semua kegiatan dengan baik namun hanya pada kegiatan Emotional activities masih kurang

Tabel 5.

Aktivitas Belajar Siswa SS1

\begin{tabular}{|c|c|c|}
\hline Subyek & Kegiatan siswa & Indikator \\
\hline \multirow[t]{4}{*}{ SS1 } & Visual activities & $\begin{array}{l}\text { Siswa dapat memperhatian dengan cukup baik media } \\
\text { yang digunakan untuk demonstrasi permaslaahan }\end{array}$ \\
\hline & Motor activities & Siswa mampu membuat konstruksi dengan tepat \\
\hline & Mental activities & $\begin{array}{l}\text { a. Siswa dapat memberikan tanggapan yang tepat dan } \\
\text { sesuai dengan permasalahan yang diberikan } \\
\text { b. Siswa mampu dengan cukup baik memecahkan soal } \\
\text { (permasalahan) dengna cara yang sesuai }\end{array}$ \\
\hline & Emotional activities & $\begin{array}{l}\text { a. Siswa terlihat sangat bersemangat dalam } \\
\text { menyelesaikan permasalahan } \\
\text { b. Siswa dengan cukup berani dalam menanggapi dan } \\
\text { mengajukan pertanyaan/pendapat dengan tegas }\end{array}$ \\
\hline
\end{tabular}

Berdasarkan tabel 5 dapat mendapatkan hasil baik. Diantaranya diketaui bahwa ST2 dalam aktivitas pada kegiatan Visual activities, Mental belajarnya beberapa telah memenuhi activities Emotional activities masih kegiatan dengan baik namun ada kurang. beberapa kegiatan yang masih belum

Tabel 6.

Aktivitas Belajar Siswa SS2

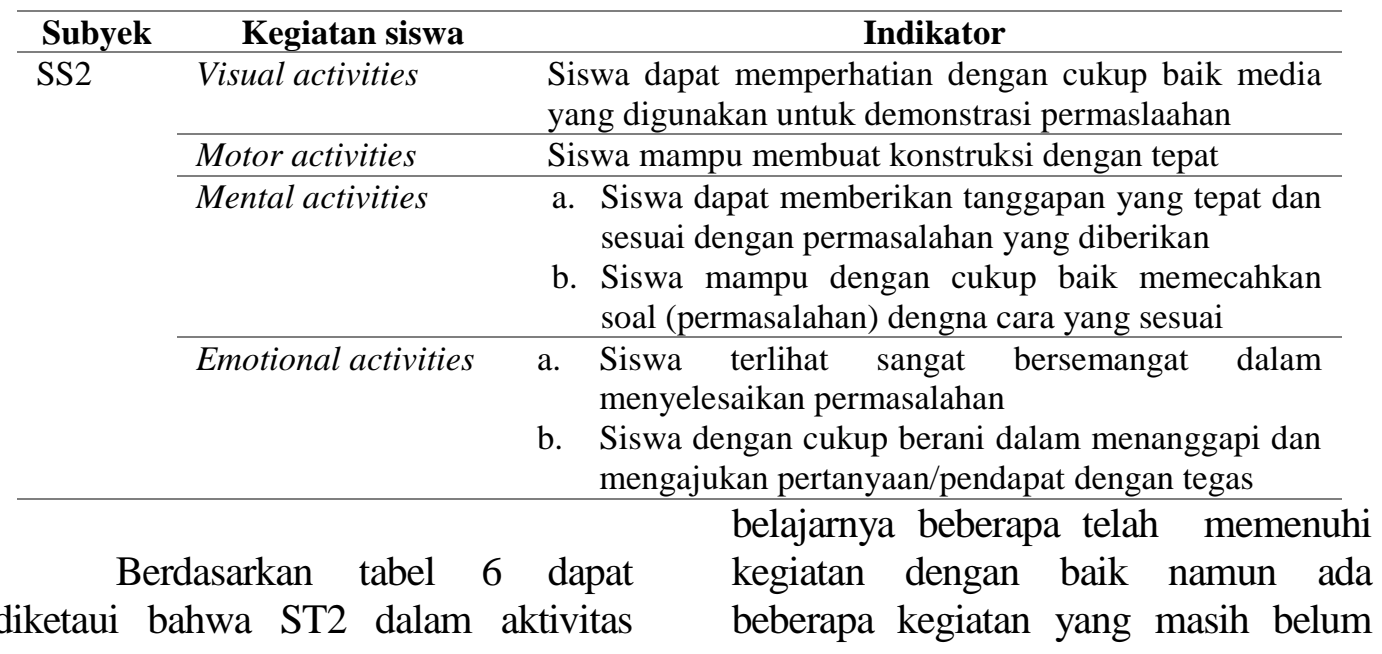


mendapatkan hasil baik. Diantaranya pada kegiatan Visual activities, Mental activities Emotional activities masih kurang.

Tabel 7.

Aktivitas Belajar Siswa SR1

\begin{tabular}{|c|c|c|}
\hline Subyek & Kegiatan siswa & Indikator \\
\hline \multirow[t]{4}{*}{ SR1 } & Visual activities & $\begin{array}{l}\text { Siswa dapat memperhatian dengan cukup baik media } \\
\text { yang digunakan untuk demonstrasi permaslaahan }\end{array}$ \\
\hline & Motor activities & $\begin{array}{l}\text { Siswa mampu membuat konstruksi dengan baik namun } \\
\text { belum tepat }\end{array}$ \\
\hline & Mental activities & $\begin{array}{l}\text { a. Siswa dapat memberikan tanggapan yang tepat dan } \\
\text { sesuai dengan permasalahan yang diberikan } \\
\text { b. Siswa mampu dengan cukup baik memecahkan soal } \\
\text { (permasalahan) dengna cara yang sesuai }\end{array}$ \\
\hline & Emotional activities & $\begin{array}{l}\text { a. Siswa terlihat cukup bersemangat dalam } \\
\text { menyelesaikan permasalahan } \\
\text { b. Siswa dengan cukup berani dalam menanggapi dan } \\
\text { mengajukan pertanyaan/pendapat dengan tegas }\end{array}$ \\
\hline
\end{tabular}

Berdasarkan tabel 7 dapat diketaui bahwa SS1 dalam aktivitas belajarnya beberapa telah memenuhi kegiatan dengan baik namun sebagian besar kegiatan yang masih belum mendapatkan hasil baik. Diantaranya pada kegiatan Visual activities, Motor activities, Mental activities, dan Emotional activities masih dalam kondisi cukup.

Tabel 8.

Aktivitas Belajar Siswa SR2

\begin{tabular}{|c|c|c|}
\hline Subyek & Kegiatan siswa & Indikator \\
\hline \multirow[t]{4}{*}{ SR1 } & Visual activities & $\begin{array}{l}\text { Siswa dapat memperhatian dengan cukup baik media } \\
\text { yang digunakan untuk demonstrasi permaslaahan }\end{array}$ \\
\hline & Motor activities & $\begin{array}{l}\text { Siswa mampu membuat konstruksi dengan baik namun } \\
\text { belum tepat }\end{array}$ \\
\hline & Mental activities & $\begin{array}{l}\text { a. Siswa dapat memberikan tanggapan yang tepat dan } \\
\text { sesuai dengan permasalahan yang diberikan } \\
\text { b. Siswa mampu dengan cukup baik memecahkan soal } \\
\text { (permasalahan) dengna cara yang sesuai }\end{array}$ \\
\hline & Emotional activities & $\begin{array}{l}\text { a. Siswa terlihat cukup bersemangat dalam } \\
\text { menyelesaikan permasalahan } \\
\text { b. Siswa dengan cukup berani dalam menanggapi dan } \\
\text { mengajukan pert } \\
\text { c. anyaan/pendapat dengan tegas }\end{array}$ \\
\hline
\end{tabular}

Berdasarkan tabel 8 dapat diketaui bahwa SS1 dalam aktivitas belajarnya beberapa telah memenuhi kegiatan dengan baik namun sebagian besar kegiatan yang masih belum mendapatkan hasil baik. Diantaranya pada kegiatan Visual activities, Motor activities, Mental activities, dan Emotional activities masih dalam kondisi cukup. 
Tabel 9

Hubungan level kinerja siswa dengan aktivitas belajar siswa

\begin{tabular}{|c|c|c|c|c|c|c|c|c|}
\hline \multirow[t]{2}{*}{$\begin{array}{l}\text { Kinerja } \\
\text { siswa }\end{array}$} & \multirow[t]{2}{*}{$\begin{array}{l}\text { Standar } \\
\text { kritis }\end{array}$} & \multirow[t]{2}{*}{ Indikator } & \multicolumn{6}{|c|}{$\begin{array}{c}\text { Aktivitas } \\
\text { belajar }\end{array}$} \\
\hline & & & ST1 & ST2 & SS1 & SS2 & SR1 & SR2 \\
\hline \multirow{8}{*}{$\begin{array}{l}\text { Practition } \\
\text { er }\end{array}$} & Clarity & $\begin{array}{l}\text { Menuliskan semua } \\
\text { yang diketahui pada } \\
\text { soal }\end{array}$ & $\sqrt{ }$ & $\sqrt{ }$ & $\sqrt{ }$ & $\sqrt{ }$ & $\sqrt{ }$ & $\sqrt{ }$ \\
\hline & & $\begin{array}{l}\text { Menyajikan } \\
\text { permasalahan pada soal } \\
\text { dalam bahasa } \\
\text { matematika dengan } \\
\text { jelas, }\end{array}$ & $\sqrt{ }$ & $\sqrt{ }$ & - & - & - & - \\
\hline & Precision & $\begin{array}{l}\text { Menuliskan semua cara } \\
\text { atau strategi yang } \\
\text { digunakan dalam } \\
\text { menyelesaikan soal } \\
\text { Menuliskan semua } \\
\text { hipotesis penyelesaian } \\
\text { soal dengan benar }\end{array}$ & $\sqrt{ }$ & $\sqrt{ }$ & $\sqrt{ }$ & $\sqrt{ }$ & $\sqrt{ }$ & $\sqrt{ }$ \\
\hline & Accuracy & $\begin{array}{l}\text { Menuliskan semua } \\
\text { informasi yang ada dari } \\
\text { soal dengan tepat } \\
\text { Semua penyelesaian } \\
\text { soal tepat }\end{array}$ & $\sqrt{ }$ & $\sqrt{ }$ & $\sqrt{1}$ & $\sqrt{ }$ & $\sqrt{ }$ & $\sqrt{ }$ \\
\hline & Relevance & $\begin{array}{l}\text { Menuliskan semua } \\
\text { konsep yang sesuai } \\
\text { dengan soal } \\
\text { Menuliskan semua } \\
\text { informasi yang terkait } \\
\text { dengan penyelesaian } \\
\text { soal }\end{array}$ & $\sqrt{ }$ & $\sqrt{ }$ & $\sqrt{ }$ & $\sqrt{ }$ & - & - \\
\hline & $\begin{array}{l}\text { Consistenc } \\
y\end{array}$ & $\begin{array}{l}\text { Menyelesaikan soal } \\
\text { yang sesuai dengan } \\
\text { informasi pada soal } \\
\text { Menyelesaikan semua } \\
\text { soal dengan } \\
\text { menggunakan cara atau } \\
\text { alternative } \\
\text { penyelesaian lain } \\
\text { dengan tepat }\end{array}$ & $\sqrt{ }$ & $\sqrt{ }$ & - & - & - & - \\
\hline & $\begin{array}{l}\text { Logical } \\
\text { Correctnes } \\
s\end{array}$ & $\begin{array}{l}\text { Menghubungkan } \\
\text { semua pengetahuan } \\
\text { sebelumnya dalam } \\
\text { menyelesaikan soal } \\
\text { Menuliskan setiap } \\
\text { alasan yang sesuai } \\
\text { dengan fakta, konsep, } \\
\text { prinsip dan operasi } \\
\text { matematika }\end{array}$ & $\sqrt{ }$ & $\sqrt{ }$ & - & - & - & - \\
\hline & $\begin{array}{l}\text { Completen } \\
\text { ess }\end{array}$ & $\begin{array}{l}\text { Menuliskan semua } \\
\text { langkah-langkah } \\
\text { penhyelesaian tahap } \\
\text { demi tahap }\end{array}$ & $\sqrt{ }$ & $\sqrt{ }$ & $\sqrt{ }$ & $\sqrt{ }$ & $\sqrt{ }$ & $\sqrt{ }$ \\
\hline
\end{tabular}




\begin{tabular}{llllllll} 
& $\begin{array}{l}\text { Menuliskan setiap hal- } \\
\text { hal terkait jawaban dari } \\
\text { penyelesaian soal. }\end{array}$ & $\sqrt{ }$ & $\sqrt{ }$ & $\sqrt{ }$ & $\sqrt{ }$ & - & - \\
\hline Fairness & $\begin{array}{l}\text { Menuliskan } \\
\text { kesimpulan disertai } \\
\text { alasan yang logis. }\end{array}$ & $\sqrt{ }$ & $\sqrt{ }$ & - & - & - & - \\
& & & & & & & \\
\end{tabular}

Berdasarkan tabel 9 disajikan bahwa untuk setiap subyek yang diambil mempunyai kemampuan memenuhi indikator pada level kinerja sesuai dengan aktivitas belajar yang telah didapat dari hasil observasi. Pada ST dapat memenuhi semua indikator pada standar kritis di level kinerja Practitioner. SS memenuhi 8 dari 15 indikator pada standar kritis di level kinerja Practitioner dan SR hanya memenuhi 4 dari 15 indikator pada standar kritis di level kinerja Practitioner.

\section{PEMBAHASAN}

Hasil penelitian yang telah diperoleh dari hasil lembar observasi selanjutnya dianalisis oleh peneliti. Hasil analisis yang diperoleh adalah sebagai berikut.

Tabel 10.

Analisis Hasil Observasi

\begin{tabular}{|c|c|c|c|c|c|c|}
\hline Kegiatan siswa & ST1 & ST2 & SS1 & SS2 & SR1 & SR2 \\
\hline Visual activities & baik & baik & $\begin{array}{l}\text { Cukup } \\
\text { baik }\end{array}$ & $\begin{array}{l}\text { Cukup } \\
\text { baik }\end{array}$ & $\begin{array}{c}\text { Cukup } \\
\text { baik }\end{array}$ & $\begin{array}{l}\text { Cukup } \\
\text { baik }\end{array}$ \\
\hline Motor activities & tepat & tepat & tepat & tepat & $\begin{array}{c}\text { Belum } \\
\text { tepat }\end{array}$ & $\begin{array}{c}\text { Belum } \\
\text { tepat }\end{array}$ \\
\hline Mental activities & $\begin{array}{l}\text { Sesuai, } \\
\text { baik }\end{array}$ & $\begin{array}{l}\text { Sesuai, } \\
\text { baik }\end{array}$ & $\begin{array}{l}\text { Sesuai, } \\
\text { cukup } \\
\text { baik }\end{array}$ & $\begin{array}{c}\text { Sesuai, } \\
\text { cukup baik }\end{array}$ & $\begin{array}{c}\text { Sesuai, } \\
\text { cukup } \\
\text { baik }\end{array}$ & $\begin{array}{l}\text { Sesuai, } \\
\text { cukup } \\
\text { baik }\end{array}$ \\
\hline $\begin{array}{l}\text { Emotional } \\
\text { activities }\end{array}$ & $\begin{array}{l}\text { Bersem } \\
\text { anagat, } \\
\text { berani }\end{array}$ & $\begin{array}{l}\text { Bersema } \\
\text { nagat, } \\
\text { cukup } \\
\text { berani }\end{array}$ & $\begin{array}{c}\text { Bersema } \\
\text { nagat, } \\
\text { cukup } \\
\text { berani }\end{array}$ & $\begin{array}{l}\text { Bersemana } \\
\text { gat, cukup } \\
\text { berani }\end{array}$ & $\begin{array}{c}\text { Berseman } \\
\text { agat, } \\
\text { cukup } \\
\text { berani }\end{array}$ & $\begin{array}{c}\text { Berseman } \\
\text { agat, } \\
\text { cukup } \\
\text { berani }\end{array}$ \\
\hline
\end{tabular}

Berdasarkan hasil tabel 10 dapat dilihat bahwa untuk siswa dengan kategori tinggi (ST) memenuhi semua kegiatan dengan baik namun pada kegiatan yang terkait keberanian masih belum dapat dikatakan selalu berani dalam menanggapi dan mengajukan pertanyaan/pendapat dengan tegas. Sedangkan untuk siswa dengan kategori sedang (SS) memenuhi 3 dari 6 kegiatan siswa dengan baik. Hasil ini sama untuk 2 subyek yang diambil. Subyek kategori Rendah (SR) memenuhi 5 dari 6 kegiatan siswa dengan baik. Hasil ini sama untuk 2 subyek yang diambil.

Hasil penelitian ini sesuai dengan pendapat Irawan, Susanto, \& Kurnianti (2015) yang menyatakan 
pada level Practitioner ini, seorang siswa sudah mulai mampu dalam memiliki strategi yang benar dalam melakukan penyelesaian masalah, mampu menghubungkan pengetahuan lama yang dimiliki oleh siswa dengan pengetahuan yang baru, serta siswa mampu mengkontruk dari suatu konsep matematika meskipun masih sebagian proses dalam pengkontruksiannya.

\section{SIMPULAN}

Simpulan dari hasil penelitian ini bahwa level kinerja Practitioner siswa mempunyai perbedaan pemenuhan standart kritisnya melalui aktivitas belajar siswa. Siswa dengan kategori kemampuan tinggi (ST) dapat memenuhi seluruh indikator standart kritis sedangkan aiswa dengan kategori kemampuan sedang (SS) dan rendah (SR) tidak dapat memenuhi.

\section{DAFTAR PUSTAKA}

Amalia, R., Panglipur, I. R., \& S, D.

A. C. (2019). Pengembangan Kartu Matematika Asyik (Karmas) untuk Menunjang Model Pembelajaran TGT (Team Games Tournament). Laplace, 1(2), 81-90.

Burwell, K., Young, V., \& Pickup, D. (2003). Taking the Lead: The Development of the Student as Reflective Practitioner in Instrumental Lessons at $\mathrm{HE}$ Level. RIME Conference, Exeter University, (August). Retrieved from http://www.tandf.co.uk/journals /titles/rime_conf/Papers/Burwel 1_Young_Pickup.pdf

Irawan, D., Susanto, \& Kurnianti, D. (2015). Pelevelan Kinerja Siswa Berdasarkan Kemampuan Berpikir Kritis Siswa Kelas VII MTS Negeri Jember dalam Menyelesaikan Soal matematika yang Terkait Tema Kopi. Kadikma, 6(3), 57-66.

Panglipur, I., R. (2006). Penerapan Model Pembelajaran Generatif Dengan Metode Pq4r (Preview, Question, Read, Reflect, Recite, Dan Review) pada Pokok Bahasan Sistem Persamaan Linier Dua.

Panglipur, I., R. (2016). Penerapan Metode Visual Finger dalam Belajar Bangun Ruang pada Anak Berkebutuhan Khusus ( Autis ). 389-392.

Panglipur, I., R., \& Putra, E., D. (2019). Analisis Level Kinerja Expert melalui Kemampuan Berpikir Kritis. Jurnal Emasains, 8(1), 24-29.

Putra, E., D. (2008). Pembelajaran Terpadu dengan Menggunakan 
Model Nested pada Mata Pelajaran Matematika Di SDN 1 Panji Lor. Skripsi.

Rahmadani, N., \& Anugraheni, I. (2017). Peningkatan Aktivitas Belajar Matematika Melalui Pendekatan Problem Based Learning bagi Siswa Kelas 4 SD. Scholaria: Jurnal Pendidikan Dan Kebudayaan, 7(3);241.

https://doi.org/10.24246/j.schola ria.2017.v7.i3.p241-250 